awareness, appearance, appetite, and thirst, when in fact the animals were dead".

"Drugs were administered to animals in a manner which made it impossible to determine how much, if any, of the required dosage was actually ingested by the animal".

- In one toxicity study, "gross changes of tissue began to appear, yet management was not made aware of these alarming changes for approximately 4 to 8 months.

- In a study done by an independent testing laboratory. FDA was told that animal tissue samples had been examined when a review of laboratory records indicates that the tissue samples had never even been collected.

Such alarming, and possible fraudu- lent, incidents are supposed to be stopped, or at least made more difficult, by FDA's proposed GLP regulations. But the regulations would in fact not be unduly burdensome. They set standards for the training of laboratory personnel, the quality of facilities and equipment, the handling of test animals, and the keeping and reporting of test data. They also specify that a Quality Assurance Unit must be established in each facility to ensure that the GLP regulations are followed. In short, the proposed standards are no more strict than those which should already be in force in any selfrespecting facility.

Perhaps the most important aspect of the proposed regulations is that they spell out a number of sanctions which FDA could invoke if violations of the GLP standards are encountered. The ultimate sanction would be to remove a product from the market if FDA had approved it on the basis of test reports subsequently found to be false or misleading. Another proposed sanction would be to disqualify a test facility as a source of information in support of a future marketing permit. Such action would be tantamount to shutting down a contract laboratory which makes its living from conducting toxicity tests for the drug industry. Finally, FDA points out that deliberate faking or misleading reporting of test results could be subject to criminal prosecution.

The proposed GLP regulations are open for comment for 120 days and FDA plans to conduct public hearings on them early next year. By that time, the results of the inspection effort should be available to provide an indication of the scope of the problem.

\title{
SEVESO
}

\section{The problems deepen}

Italian authorities are now pondering how to clean up an area near Scveso in northern ltaly, following an accident last July which released large quantities of dioxin into the environment. Some important new information bearing on the problem has surfaced in the United States. Colin Norman reports

Dioxin in the soil of the most heavily contaminated arca near Seveso can be expected to take up to 14 years to break down to levels at which the compound can no longer be detected. But there is unlikely to be much, if any, movement of dioxin in the soil, and the contamination will probably be confined to the upper 12 inches for a long time.

Those conclusions have emerged from an analysis of previously undisclosed studies conducted by the US Air Force, and from information gathered as a result of a bizarre dioxin contamination incident in Missouri in the early 1970s. The studies were ferreted out and analysed by Barry Commoner and Robert E. Scott, researchers at the Center for the Biology of Natural Systems at Washington University. Scott and Commoner have sent their conclusions to authorities investigating the Seveso disaster.

The Air Force studies, which were released to Commoner on October 28 , involved soil tests with military herbicides contaminated with dioxin, left over from the Vietnam war. They involved heavy spraying of plots of land in Utah, Kansas and Florida, and subsequent monitoring of dioxin levels in the soil. Commoner and Scott conclude from the studies that the likely half-life for breakdown of dioxin in the soil at Seveso is about 250 days, a rate which suggests that it would take about 14 years for contamination to disappear from the most heavily affected area (Zone $A$ ) and about seven years to degrade to undetectable levels (about 10 parts per trillion) in the surrounding zone (Zone B).

But, in spite of an annual rainfall of about 60 inches in Florida, the Air Force study indicated that dioxin in the test plot there did not migrate in the soil. That finding is particularly important because there has been recent heavy rainfall in Seveso which has led to worries that the dioxin may have been washed through the soil into the groundwater. "It may be expected that the TCDD present in the upper layers of the soil at Seveso wil probably not migrate downward significantly, in spite of the heavy rainfall", Commoner and Scott conclude. Those observations lead them to note that if the soil at Seveso is left in place, contamination is unlikely to spread, but alternatively if the upper layers of soil are stripped off and replaced with fresh soil, any dioxin left in the lower layers would not be expected to migrate to the surface.

The Air Force study has also yielded information on the effects of low levels of dioxin on wildlife. Samples of wildlife around the Florida test plot indicated significant bioaccumulation of the contaminant, and there was also a marked drop in the fertility of beech mice in the area. The observations lead
Commoner and Scott to conclude that wildlife at Seveso will be affected unless soil concentrations can be reduced to about 500 parts per trillion, compared with the average concentration of ahout 10 parts per million in Zone A. Such a reduction, they note, "could be most rapidly achieved by removing the upper layer of soil and replacing it with uncontaminated soil".

The other information analysed by Commoner and Scott was derived from observations following an incident in which waste oil heavily contaminated with dioxin was sprayed on the ground in four places in Missouri in May and June, 1971. The dioxin contamination was unknown at the time.

One application involved spraying the ground in a horse arena shortly before a show to keep down dust. Hundreds of birds and several horses died as a result of exposure to dioxin and three months later a young girl who had been playing in the arena was admitted to hospital with symptoms ranging from nosebleeds and headaches to severe disuria and hematuria. In October, four months after the spraying, between six and eight inches of topsoil was removed from the area and replaced with fresh soil, but deaths of horses, cats and other wildlife persisted. In April, 1974, four ycars after the accident, a further six inches of soil was removed, whereupon the toxic effects disappeared.

The original contamination in the arena was reckoned to be about 30 parts per million, a level similar to that in Zone $\mathbf{A}$, and thus the observations compiled by Commoner and Scott are directly relevant to the Seveso investigation.

Commoner and Scott conducted 
their study under the auspices of the Scientists Institute for Public Information.

- Alastair Hay adds : At the time of the Seveso explosion, 150 women resident in the area were in the first trimester of pregnancy. Most of the women applied for a therapeutic abortion when informed of the teratogenic properties of dioxin. Following examination by health officials of 730 pregnant women formerly resident in the contaminated area, only 29 have had the operation. The foetuses removed from these women are currently being examined for any signs of abnormality.

Professor Francesco Cefis of the Instituti Clinici di Perfezionamento in Milan, and Professor Alfred Gropp, Head of the Pathology Depjartment of Lübeck Medical School in Germany, are in charge of the investigations. Neither would comment last week on the results of their observations so far. Only five of the 29 foetuses have been examined and Profesor Cefis estimated that it would take another two months to complete the study. By then women who were in the earlier stages of pregnancy in July will be six or seven months pregnant-too late for an abortion to be performed.

The rate of spontaneous abortions in the Seveso area is reported to have increased to twice the Italian national average since July. The rate of miscarriage was reported to have increased similarly in Vietnam following spraying with the herbicide 2,4,5-T. Both the trichlorophenol discharged at Seveso and the 2,4,5-T used in Vietnam contained dioxin. The Vietnamese authorities maintain that dioxin was responsible for the miscarriages

\section{Towards anticipating disaster}

In Britain last week the Insurance Technical Bureau (ITB), which leading insurance groups established in 1972 as a non-profit making organisation with "technical expertise in the field of industrial loss prevention". demonstrated 'Anticipator', a new' system designed to alert managers of chemical plants to potential hazards in their site installations.

One of the recommendations made by the 1974 Court of Inquiry into the Flixborough disaster was that some form of recorder should be made available to monitor operating conditions in industrial installations. This would perform a function similar to that of the 'black box' flight recorder in aircraft. 'Anticipator' is a sophisticated monitoring system with its own computer which will register information about pressure, temperature, flow rates, gas leaks, vibrations and other factors relevant to the safe operation of a chemical plant. It can be preprogrammed to record only data which fall outside normal working parameters. making interpretation a relatively simple process.

The designers argue that incidents usually "cast their shadows before them", and feel certain that Anticipator would have prevented accidents such as those at Flixborough and Seveso. With the primary research and development work now completed at a total cost of $£ 50,000$, the ITB propose to find a commercial concern to develop the system for marketing. The trouble is, the biggest firms do their own monitoring, and the smaller ones may not be able to afford the new device.

Alastair Hay which they recorded.

Meanwhile, the scientific commission responsible for formulating a policy to decontaminate the area containing dioxin has still not agreed upon methods to be employed. Frustration at the apparent inactivity has been expressed both by experts anxious to begin the work of decontamination, and by former residents of the area who last week tore down protective fences in protest at the delay.

The work of the commission has been hampered by the disagreement among experts concerning the amount of dioxin to be dealt with. Dr Donald Lee of the Plant Pathology Laboratory at Harpenden, UK, suggests that $130 \mathrm{~kg}$ of dioxin was released in the explosion, and Professor Samuel Ep- stein of the University of Illinois, considers the figure of $300 \mathrm{lb}$ of dioxin to be "about right". But a group of chemical engineers invited by the commission to submit a programme for decontamination estimate that $1-3 \mathrm{~kg}$ of dioxin was released, a figure based on results obtained from a simulation of the explosion.

The two top officials of ICMESA, who after being arrested and charged with culpably causing a disaster were released on bail to supervise decontamination work within the ICMESA plant, have since been rearrested and criminal proceedings have begun. The criminal prosecution will be conducted at the same time as the civil proceedings brought against HoffmanLa Roche, ICMESA's owners, by the Italian authorities.

\section{EEC}

\section{Manoeuvring for agreement}

The EEC's Council of Research Ministers met in Brussels last week to discuss once again the Joint European Torus (JET), the Community's fusion project, and the research programme for the Community's Joint Research Centre (JRC). Chris Sherwell reports

So near and yet so far. The EEC now looks sufficiently close to agreement on the site for JET that the small step the Council of Research Ministers took at their meeting last week may in retrospect come to look like a giant leap for the Community. But because there is still ample scope for more than one hitch, the prospect could be as much for a leap backwards as a leap for- wards.

On paper the progress that everyone is keen to say really did occur in Brussels certainly looks very slight. The Council reached just one firm decision with any consequence in terms of action or expenditure. This was that the Community's fusion programme, which is undertaken by a number of associated laboratories in the member states but does not include JET, could go ahead for another four years.

To call that insignificant, though, is to reckon without the intricacies and nuances of Community deliberations. Until now there has been no agreement on expenditure for the full five years of the fusion programme. When the programme first came up for discussion last December, Italy refused consent, saying she could not agree without a decision on a site for JET. She modified this position at a February Council meeting, allowing just one year's expenditure. In the view of one senior official in Brussels, therefore, the absence last week of continued further blocking of the programme from Italy means that the decision can be interpreted as a positive sign for JET.

What changed Italy's mind? The answer is to be found in the way the JET argument has developed. Italy's concern has always been principally over the fate of Ispra, one of the four establishments constituting the JRCthe others are in Germany, Belgium and the Netherlands, but Ispra is the largest with two-thirds of the JRC staff. By the last Council meeting in October it had become clear that progress on 